\title{
IMPACT OF FINANCIAL INCLUSION ON FINANCIAL STABILITY BASED ON INCOME GROUP COUNTRIES
}

\author{
Azka Azifah Dienillah', Lukytawati Anggraeni², Sahara²
}

\begin{abstract}
Financial inclusion is one of strategies to increase inclusive growth in a lot of countries. However it may cause either stability or instability in the financial system and the impact can be different among income group countries. Potential instability in the financial system occurs when financial inclusion causes reduction in credit standard, inceasing risk of bank reputation, and uncoresponding regulation in microfinance. Therefore, this research aimed to measure financial inclusion and financial stability indexes between countries and analyze the impact of financial inclusion on financial stability in 19 countries based on income group from 2004-2014. Data were collected from World Bank, the International Monetary Fund (IMF) database, and other sources. The methods used Sarma index to calculate financial inclusion, Albulescu and Goyeau index to calculate financial stability, and Tobit model to analyze the impact of financial inclusion on financial stability. The results show higher income countries have higher financial inclusion and financial stability index than lower income countries. Financial inclusion only has positive significant effect to financial stability in high income countries. Lower and upper middle income countries have to increase availability of financial services to enhance financial inclusion. Moreover, lower and upper middle income countries have to increase financial development to enhance financial stability.
\end{abstract}

Keywords: financial inclusion index, financial stability index, Tobit model

JEL Classification: G21, G32, C23

1 Author is research assistant of Bank Indonesia.

2 Author is economic lecturer of Bogor Agricultural University 


\section{INTRODUCTION}

Financial inclusion becomes an important program at national and international level because there are 2.6 billion people or more than $50 \%$ of world population not having access to credit, insurance, and savings (CGAP, 2013). Financial inclusion program is expected to increase inclusive growth in many countries. Increasing in financial inclusion enhances based deposit as source of credit. The credit can improve real sector peformance. These will reduce poverty, improve income distribution, and improve the stability of the financial system in order to achieve growth that is felt by the entire community (Khan, 2011).

Seriousness of the international communities in implementing the program of financial inclusion can be seen from increasing of formal financial services products. Figure 1 below shows an average increase of outstanding loans from 2004 to 2011. Upper middle income countries group has the highest average growth of outstanding loans. The percentage of outstanding loans growth in upper middle income countries group is $13.3 \%$. Lower middle income countries group has negative growth of loans per 1,000 adult population. The growth rate of lower middle income countries group is negative $8.3 \%$. Average world has positive credit accounts per 1,000 adult population growth rate amount of $8.1 \%$.

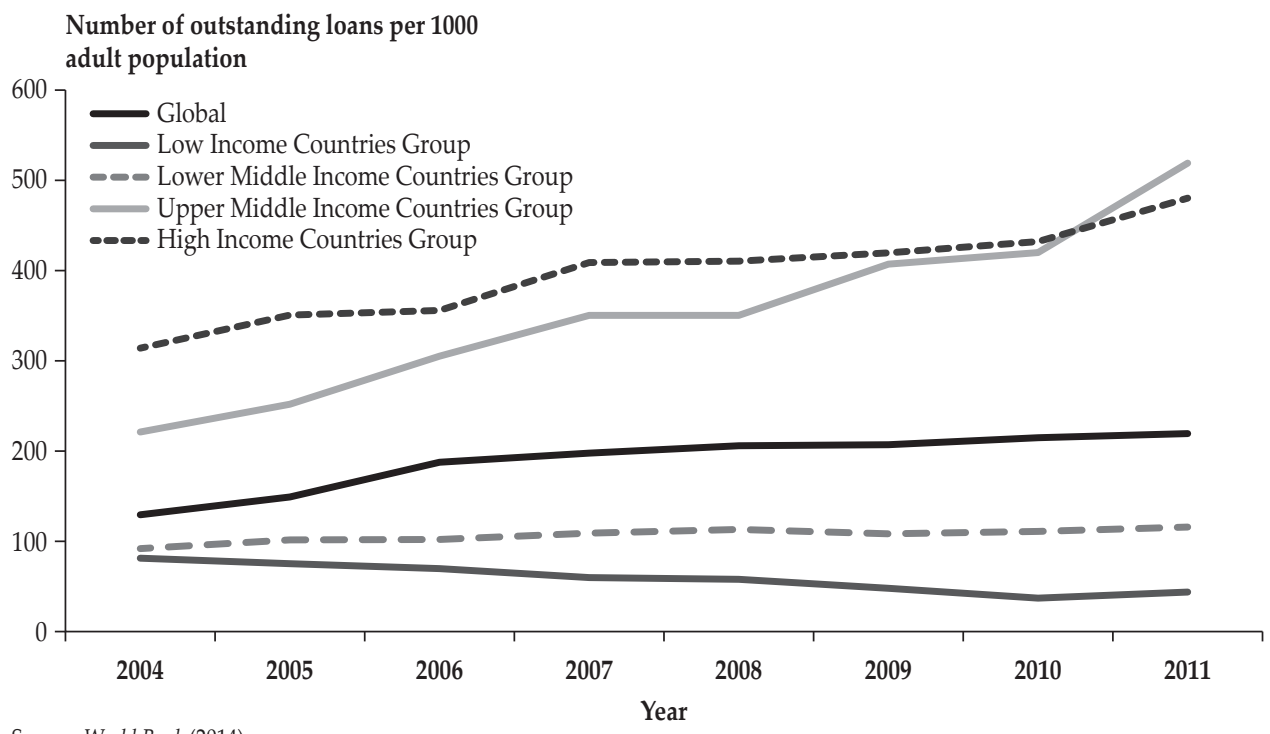

Source: World Bank (2014)

Figure 1. Number of outstanding loans per 1000 adult population based on income level in 2004-2011

There are few studies about the impact of financial inclusion on financial stability with different result. Some studies about the impact of financial inclusion on financial stability which show the positive impact was conducted by Dienillah (2015), Morgan and Pontines (2014), Cull and Kunt (2007), and Huang and Ratnovski (2011). Meanwhile, some studies which show potential negative impact 
of financial inclusion on financial stability undertaken by Dupas et al. (2012) and Khan (2011). Since there are different result of the impact of financial inclusion on financial stability, we need more research about this topic.

In the theory, high level of financial inclusion will be followed by strong financial system and people with lower income level should have a better impact of financial inclusion on financial stability than people with higher income (CGAP, 2013). This is because people with higher income have a faster response when the crisis happen than people with lower income. The response can be seen from the massive withdrawal of higher-income customers when a crisis occurs. But, from some studies and fact have not confirmed these theory so further research is needed.

Han and Melecky (2013) state that financial inclusion has a positive impact on financial stability in high income countries and upper middle income countries. This is because increasing in financial inclusion can improve deposits in commercial bank so it will make resilience of the funding base of deposits in banking sector when crisis occurs. In contrast to high-income countries group and upper middle income group, the lower middle income countries group has the potential instability in financial system due to financial inclusion (Khan, 2011).

Previous studies about the impact of financial inclusion on financial stability still use a proxy to represent the level of financial inclusion and a level of financial stability. Morgan and Pontines (2014) suggest to include other variables in describing financial inclusion and financial stability since financial inclusion is not only seen by financial products indicator such as SMEs outstanding loans but also seen by penetration and product access to formal financial institutions indicators (Sarma, 2008). The stability of the financial system is not only seen by Bank Z score because the financial system is not only influenced by the banking sector, but also influenced by the state of real economy, households, corporations, external factors, and so on. So it is necessary to build a more representative index describes the financial inclusion and stability of financial system. Therefore, the problem in this research are:

1. How is the performance of financial inclusion among countries based on income group countries in 2004-2014?

2. How is the performance of the financial system stability among nations based on income group countries in 2004-2014?

3. What is the impact of financial inclusion on the stability of the financial system based on income group countries in 2004-2014?

Based on the description above, the purpose of this research are to:

1. Calculate and describe index of financial inclusion among countries based on income group countries in 2004-2014.

2. Calculate and describe index of financial stability among countries based on income group countries in 2004-2014.

3. Analyze the impact of financial inclusion on financial stability based on income group between countries in 2004-2014. 


\section{THEORY}

\section{1 Concept of Financial Inclusion}

These are various definitions of financial inclusion from some researchers and institution:

Table 1.

Definitions of Financial Inclusion

\begin{tabular}{|c|c|c|c|c|}
\hline No. & Authors & Year & Publication & Definition \\
\hline 1 & $\begin{array}{l}\text { Mandira } \\
\text { Sarma }\end{array}$ & 2012 & $\begin{array}{l}\text { Index of Financial } \\
\text { Inclusion -a } \\
\text { measure of } \\
\text { Financial Sector } \\
\text { Inclusiveness }\end{array}$ & $\begin{array}{l}\text { Financial inclusion as a process that ensures the } \\
\text { ease of access, availability and usage of the formal } \\
\text { financial system for all members of an economy. }\end{array}$ \\
\hline 2 & $\begin{array}{l}\text { The Reserve } \\
\text { Bank of India }\end{array}$ & 2008 & $\begin{array}{l}\text { Financial Inclusion } \\
\text { - from Obligation } \\
\text { to Opportunity }\end{array}$ & $\begin{array}{l}\text { Financial inclusion is the process of ensuring access } \\
\text { to financial services and timely and adequate credit } \\
\text { where needed by vulnerable groups such as weaker } \\
\text { sections and low income groups at an affordable } \\
\text { cost }\end{array}$ \\
\hline 3 & Harun R Khan & 2012 & $\begin{array}{l}\text { Issues \& } \\
\text { Challenges } \\
\text { in Financial } \\
\text { Inclusion:Policies, } \\
\text { Partnerships, } \\
\text { Processes \& } \\
\text { Products }\end{array}$ & $\begin{array}{l}\text { Viable and sustainable business models with } \\
\text { focus on accessible and affordable products and } \\
\text { processes, synergistic partnerships with technology } \\
\text { service providers for efficient handling of low } \\
\text { value, large volume transactions and appropriate } \\
\text { regulatory and risk management policies that } \\
\text { ensure financial inclusion and financial stability } \\
\text { move in tandem. }\end{array}$ \\
\hline
\end{tabular}

The level of financial inclusion can be measured by an Index of Financial Inclusion (IFI). Some researchers measure financial inclusion by calculating the proportion of adult or household populations who have access to formal financial services. IFI developed by Sarma (2008) are based on three dimensions, namely banking penetration, availability of banking services, and usability.

a. Banking Penetration

Inclusive financial systems must be reachable or widely accessible among users. Banking penetration can be represented from the proportion of adult people that have an account at the bank. Indicator of banking penetration in this study uses the percentage of total accounts in formal financial institutions to total population over 15 years and the percentage of SMEs that have accounts in formal financial institutions.

b. Availability of financial services

Inclusive financial systems must be available to all users. In the sarma study, availability indicator is represented by the number of outlets (branches, ATMs, etc.). In addition to Sarma (2012), Camara and Tuesta (2014), and Consultative Group to Assist the Poor (2012) also stated that the availability of financial services can be indicated by the number of branches in financial institutions or ATMs (Automatic Teller Machine). 
c. Usability

Despite having access to financial services, there is still a group of people not yet able to utilize the existence of financial services. Therefore, having an account is not enough to show a level of financial inclusion. Financial inclusion can be demonstrated in the use of financial services such as credits, deposits, payments, remittances, and transfers. Indicators used in Sarma (2012) are Outstanding loans from commercial banks (\% to GDP) or Outstanding deposits with commercial banks (\% to GDP), Meanwhile, usability indicators in Morgan and Pontines (2014) and Consultative Group to Assist the Poor (2012) is more specialized in the use of loans by small and medium enterprises (SMEs).

\section{2 Concept of Financial Stability}

According to the publication of Asean Development Bank Institute (2014), there is no general agreement for the definition of financial stability but many institutions and researchers have tried to define it based on the experiences of some countries and previous studies. Bank Indonesia (2007) stated that Financial System Stability (SSK) is a stable financial system that capable of allocating resources and absorbing shocks that can prevent disruption to real sector activities and financial system. Then according to the European Central Bank (2012), financial system stability is a condition that the financial system can overcome shock and reduce barriers in the process of financial intermediation.

Based on studies that conducted by Hawkins and Klau (2000), Nelson and Perli (2005), Gray et al. (2007), and Cheang and Choy (2011), there are some sectors that can affect the stability of the financial system:

a. Real Economic Sector

There are four variables of the real sector of the economy that can affect the stability of the financial system, namely GDP growth, government tax position, global oil price index, and domestic inflation.

b. Corporate Sector

There are four variables of the corporate sector that can affect the stability of the financial system. These variables are the ratio of credit per equity, expenditure on interest, net foreign exchange exposure to equity ratio, and corporate failure.

c. Household Sector

There are five variables of the household sector that can affect the stability of the financial system. These variables are household assets, household credit, household income, household consumption, as well as household credit services and principal payments.

d. External Sector

There are six variables of the external sector that can affect the stability of the financial system. These variables are real exchange rate, current account, capital flows, global inflation, global GDP, and global economic climate.

e. Financial Sector

There are seven variables of the financial sector that can affect the stability of the financial system. These variables are monetary aggregate (saving, transaction, total credit), money supply, ratio of domestic credit to GDP, interest rate 
spread, bank profitability (ROA and ROE), real interest rate, banking sector risk (non-performing loan), capital adequacy, liquidity, credit rating of banks, Bank Z-Score, and banking concentration.

f. Financial Market Sector

There are five variables of the financial market sector that can affect the stability of the financial system. These variables are changes in stock index, distribution of corporate bonds, market capitalization, market liquidity, volatility, and housing prices.

\subsection{Previous Studies}

One of previous studies that analyzed the impact of financial inclusion on financial stability is Han and Melecky (2014). The result is high income countries and middle income countries should increase the access to deposit ratio. It may increase the resilience of the funding base of banking sector deposits at financial stress. The positive impact between financial inclusion and financial stability was also found in Adasme, Majnoni and Uribe (2006) about Chile. The result is an increase in loans by SMEs lowering risk from portfolio bank loans which means increasing the stability of the financial system.

Khan (2011) conducted research about middle income countries. His study stated that financial inclusion has either positive or negative impacts on financial system stability (Khan 2011). Positive impacts arise if financial inclusion can increase the diversification of banking assets and increase monetary policy transmission. While the negative impact is due to financial inclusion may decrease the credit standard. It may cause instability of mcrofinance institutions.

Furthermore, Dupas et al. (2012) with an experimental research in the western province of Kenya, which is a low-income country, has found out that increasing in availability of banking services did not lead to increasing in financial stability. This is because the increasing in financial inclusion is not followed by lower cost of borrowing money for the lower middle class, lack of trust, and not followed by improving the quality of services.

\section{METHODOLOGY}

\subsection{Types and Sources of Data}

The data used is secondary data which is an annual data with an unbalanced panel data structure. The panel data consist of a cross section data (five lower middle income countries, nine upper-middle income countries, and five highincome countries) and time series data from 2004 to 2014. The data were collected from various sources such as: World Bank, World Development Indicators (WDI), International Monetary Fund (IMF) database, and other sources. This research was conducted with software such as STATA and Microsoft Excel. 
Table 2.

Information about Data, Unit, and Sources

\begin{tabular}{|c|c|c|}
\hline Indicator & Unit & Source \\
\hline \multicolumn{3}{|l|}{ Financial Stability Index } \\
\hline \multicolumn{3}{|l|}{ Financial Development Index (FDI) } \\
\hline Market Capitalization/GDP & $(\%)$ & IFS IMF \\
\hline National Currency Credit/GPD & $(\%)$ & World Bank \\
\hline Interest Rate Spread & $(\%)$ & World Bank \\
\hline Bank Concentration & $(\%)$ & World Bank \\
\hline \multicolumn{3}{|l|}{ Financial Vulnerability Index (FVI) } \\
\hline Inflation, Consumer Prices & $(\%)$ & IFS IMF \\
\hline General Balance, Deficit or Surplus/GDP & $(\%)$ & World Bank \\
\hline Current Account/GDP & $(\%)$ & World Bank \\
\hline Real Effective Exchange Rate (change) & $(\%)$ & World Bank \\
\hline Non Governmental Credit/Total Credit & $(\%)$ & World Bank \\
\hline Loan/Deposits & $(\%)$ & World Bank \\
\hline Deposit/M2 & $(\%)$ & World Bank \\
\hline \multicolumn{3}{|l|}{ Financial Soundness Index (FSI) } \\
\hline Bank Non-Performing Loans To Gross Loans & $(\%)$ & World Bank \\
\hline Bank Capital To Total Assets & $(\%)$ & World Bank \\
\hline Bank Return on Asset (ROA) & $(\%)$ & World Bank \\
\hline Bank Z-Score & $(\%)$ & World Bank \\
\hline \multicolumn{3}{|l|}{ World Economic Climate Index } \\
\hline World Inflation, Consumer Prices & $(\%)$ & IFS IMF \\
\hline World GDP growth & $(\%)$ & IFS IMF \\
\hline Economic Climate Index & Index & CESifo \\
\hline \multicolumn{3}{|l|}{ Financial Inclusion } \\
\hline Penetration (Number of Bank Accounts per 1,000 adults) & Index & IMF \\
\hline Availability (Number of Bank Branches per 100,000 adults) & Index & IMF \\
\hline Usability (Outstanding Loans as Percent of GDP) & $(\%)$ & IMF \\
\hline Usability (Outstanding Deposits as Percent of GDP) & $(\%)$ & World Bank \\
\hline \multicolumn{3}{|l|}{$\begin{array}{ll}\text { Other Factors } \\
\end{array}$} \\
\hline Non-Performing Loan to Gross Deposit & $(\%)$ & World Bank \\
\hline GDP per capita & $\begin{array}{l}\text { USD / } \\
\text { person }\end{array}$ & World Bank \\
\hline $\begin{array}{l}\text { Private credit by deposit money banks and other financial institutions to } \\
\text { GDP }\end{array}$ & $(\%)$ & World Bank \\
\hline Non-FDI capital flow to GDP & Index & World Bank \\
\hline Financial Openness & Index & Chinn-Ito database \\
\hline Liquid assets to deposits and short-term funding & $(\%)$ & World Bank \\
\hline
\end{tabular}




\subsection{Financial Inclusion Index}

Calculation of Financial Inclusion index in this research uses a method developed by Sarma (2008). There are three dimensions in this calculation such as banking penetration (number of deposit accounts at commercial bank per 1,000 adult population), the availability of banking services (number of branches of commercial bank per 100,000 population) and usability (total of the proportion of loans and deposit to GDP). These are the steps of calculation:

1. Calculating the value of the indicator on each dimension that has been weighted.

$$
\mathrm{d}_{\mathrm{i}}=\mathrm{w}_{\mathrm{i}} \frac{A_{i}-m_{i}}{M_{i}-m_{i}}
$$

Where:

$w_{i}=$ weight for dimension $i, 0 \leq w_{i} \leq 1 ; A \_i=$ Current value of the variable $i$.

$\mathrm{m} \_\mathrm{i}=$ minimum value of the variable $\mathrm{i} ; \bar{M}_{-} \mathrm{i}=$ maximum value of the variable $\mathrm{i}$.

2. Calculating the value of $X_{1}$ and $X_{2}$

$$
\begin{aligned}
& X_{1}=\frac{\sqrt{d_{1}^{2}+d_{2}^{2}+d_{3}^{2}}}{\sqrt{w_{1}^{2}+w_{2}^{2}+w_{3}^{2}}} \\
& X_{2}=1-\frac{\sqrt{\left(w_{1}-d_{1}\right)^{2}+\left(w_{2}-d_{2}\right)^{2}+\left(w_{3}-d_{3}\right)^{2}}}{\sqrt{w_{1}^{2}+w_{2}^{2}+w_{3}^{2}}}
\end{aligned}
$$

3. Calculating the value of the Financial Inclusion Index $=\frac{1}{2}\left[X_{1}+X_{2}\right]$

Range of financial inclusion index is between 0 until 1 . Country category based on financial inclusion index value is as follows:

Index $<0.3=$ Countries with low level of financial inclusion.

$0.3 \leq$ index $<0.6=$ Countries with moderate level of financial inclusion.

$0.6 \leq$ index $=$ Countries with a good level of financial inclusion.

\subsection{Financial System Stability Index}

Calculation of financial stability index in this study uses a method developed by Albulescu and Goyeau (2010). There are 18 indicators in this calculation. These indicators represent some of the sub-indexes making up the index of financial stability. The constituent sub-indexes include the Financial Development Index, Financial Vulnerability Index, Financial Soundness Index, and the World Economic Climate Index. Steps of financial stability index calculation are as follow: 
1. Normalizing each indicator value with the following formula:

$$
\mathrm{I}_{\mathrm{it}} \mathrm{n}=\frac{I_{i t}-\operatorname{Min}\left(I_{i}\right)}{\operatorname{Max}\left(I_{i}\right)-\operatorname{Min}\left(I_{i}\right)}
$$

Where:

$\mathrm{I}_{\mathrm{it}} \mathrm{n} \quad=$ value of variable that has been normalized.

$\mathrm{I}_{\text {it }}^{\text {it }} \quad=$ current value of $\mathrm{i}$ variable.

Min $\left(\mathrm{I}_{\mathrm{i}}\right)=$ minimum value of $\mathrm{i}$ variable;

$\operatorname{Max}\left(\mathrm{I}_{\mathrm{i}}\right)=$ maximum value of $\mathrm{i}$ variable.

2. Calculating sub-indexes of financial stability index.

$$
\bar{D}_{\mathrm{t}}=\frac{\sum_{i=1}^{4} D_{i t}}{4}(6), \bar{V}_{\mathrm{t}}=\frac{\sum_{i=1}^{8} V_{i t}}{7}(7), \bar{S} \mathrm{t}=\frac{\sum_{i=1}^{5} S_{i t}}{4} \quad(8), \quad \bar{W} \mathrm{t}=\frac{\sum_{i=1}^{3} W_{i t}}{3}
$$

Where:

$\bar{D}_{t}=$ value of financial development index which is the average value of all the constituent indicators in t-period.

$\bar{V}_{\mathrm{t}}=$ value of financial vulnerability index which is the average value all indicators constituent in t-period.

$\bar{S}_{t}=$ value of financial soundness index which is an average value of all indicators constituent in t-period.

$\bar{W}_{\mathrm{t}}=$ value of world economy climate index which is an average value of all indicators constituent WECI in t-period.

3. Finally, the aggregate financial stability index is composed as follows:

$$
\mathrm{AFSI}=\frac{4 \bar{D}_{t}}{18}+\frac{7 \bar{V}_{t}}{18}+\frac{4 \bar{S}_{t}}{18}+\frac{3 \bar{W}_{t}}{18}
$$

Financial system stability index has a value between 0 and 1 . If the index value close to 0 means that the country has an unstable financial system, while if the value close to 1 means that the country has a stable financial system. But increasing in some indicators such as Bank Non-Performing Loans to Gross Loans, Inflation, Interest Rate Spread, World Inflation, and Non-Performing Loan to Gross Deposit will reduce value of sub-indexes.

\subsection{Analysis The Impact of Financial Inclusion on Financial Stability} In analyzing the impact of financial inclusion on financial stability in Asia, the equation used is composed as follows:

$$
\mathrm{AFSI}_{\mathrm{it}}=\mathrm{b}_{1}+\mathrm{b}_{2} \mathrm{IFI}_{\mathrm{it}}+\mathrm{b}_{3} \mathrm{CGDP}_{\mathrm{it}}+\mathrm{b}_{7} \mathrm{OPNS}_{\mathrm{it}}+\mathrm{e}_{\mathrm{it}}
$$


Where :

AFSI $_{\text {it }}$ : Index of Financial Stability for country i year $t$ (index).

IFI $_{\text {it }} \quad$ : Financial Inclusion Index for country i year $t$ (Index).

$\mathrm{CGDP}_{\text {it }}$ : The ratio of private credit from bank deposits and other financial institutions of GDP for country i year $\mathrm{t}(\%)$.

$\mathrm{OPNS}_{\mathrm{it}}$ : Financial openness index (financial openness) for country i year to $\mathrm{t}$ (Index).

$\mathrm{e}_{\mathrm{it}} \quad$ : Error for country i year $\mathrm{t}$.

\section{RESULT AND ANALYSIS}

\subsection{Financial Inclusion Based on Income Group Countries}

Table 3 shows the average Financial Inclusion Index (IFI) based on the Income Group Countries consisting of lower middle income countries, upper middle, and high income countries. The financial inclusion index consists of three dimensions that represent access to banking sector $\left(d_{1}\right)$, financial services availability $\left(d_{2}\right)$, and usability $\left(\mathrm{d}_{3}\right)$.

Table 3.

Financial Inclusion Index by Income Level Group of Countries

\begin{tabular}{lcccc}
\hline \multirow{2}{*}{ Group } & \multicolumn{4}{c}{ Average } \\
\cline { 2 - 5 } & $\mathrm{d}_{1}$ & $\mathrm{~d}_{2}$ & $\mathrm{~d}_{3}$ & IFI \\
\hline LMIC & 0.1128915 & 0.045201 & 0.20532 & 0.130108 \\
UMIC & 0.242146 & 0.191096 & 0.260257 & 0.242013 \\
HIC & 0.5990889 & 0.414563 & 0.490407 & 0.496548 \\
\hline
\end{tabular}

Where:

LMIC : Lower Middle Income Countries.

UMIC : Upper Middle Income Countries.

HIC : High Income Countries.

$\mathrm{d}_{1} \quad$ : dimension of access to banking sector with normalized data.

$\mathrm{d}_{2}$ : dimension of financial services availability with normalized data.

$\mathrm{d}_{3}^{2} \quad$ : dimension of financial services usability with normalized data.

IFI : Index of Financial Inclusion.

Table 3 shows that high income countries group has the highest average index of financial inclusion. The financial inclusion index is valued at 0.49 where the value is more than 0.3 , which means high income countries group is the group of countries with moderate financial inclusion (Sarma, 2008). High income countries group has the highest average index of financial inclusion since high income countries group has high value of banking penetration dimension represented by the number of deposit accounts at commercial bank per 1,000 adult population, availability of financial services dimensions represented by a number of commercial bank branches per 100,000 population adults, and product usability of formal financial institutions dimensions represented by the proportion of outstanding loans and deposit to GDP. 
Upper-middle income countries has an average value of financial inclusion index at 0.24 . The index value is less than 0.3 so classified in the group of countries with poor financial inclusion (Sarma, 2008). Dimension that contribute the greatest value on the financial inclusion index in upper middle income countries group is dimension of financial services usability. It is represented by the relatively high proportion of outstanding loans and deposit to GDP compared to other dimensions. The obstacles in the implementation of financial inclusive in Uppermiddle income countries group is lack of financial services illustrated by low number of branches provided by commercial banks.

Lower middle income countries group has the lowest average value of financial inclusion index at 0.13 . The index value is less than 0.3 so classified in the group of countries with poor financial inclusion (Sarma, 2008). All dimension of financial inclusion in the group of middle income countries is the lowest compared to other groups. Moreover, the lowest dimension in lower middle income group of countries is availability of financial services illustrated by the low number of branches provided by commercial banks.

\subsection{Financial Stability Based on Income Group Countries}

Table 4 shows the results of calculation for the average financial stability index based on Income Group Countries. Financial system stability index is composed of four sub-indexes representing the development of financial sector, the vulnerability of financial sector, the soundness of financial sector, and world economic climate. From the calculation results obtained as follows:

Table 4.

Financial System Stability Index Based on Income Group Countries

\begin{tabular}{lccccc}
\hline \multirow{2}{*}{ Group } & \multicolumn{5}{c}{ Average } \\
\cline { 2 - 6 } & FDI & FVI & FSI & WECI & AFSI \\
\hline LMIC & 0.2986871 & 0.392638 & 0.597476 & 0.652325 & 0.46056 \\
UMIC & 0.398602 & 0.496787 & 0.582886 & 0.638334 & 0.517693 \\
HIC & 0.5982915 & 0.547644 & 0.531516 & 0.671236 & 0.575914 \\
\hline
\end{tabular}

Where:

FDI : Financial Development Index; FVI: Financial Vulnerability Index

FSI : Financial Soundness Index; WECI: World Economic Climate Index.

AFSI : Aggregate Financial Stability Index

Table 4 shows that the group of countries having the highest value of an average financial stability index is high income countries group. The high index of financial stability in high-income group of countries due to the relatively high constituent sub-indexes such as the Financial Development Index and Financial Vulnerability Index. The high index of financial development is illustrated by the high average value of capital in the financial markets, high value of domestic credit, low interest rate spreads, and high concentration of banking sector. Then, the high index of financial vulnerability is illustrated by the low rate of inflation and high real effective exchange rate. 
Either lower middle income countries group or upper middle income countries group has lower value of financial stability index than high-income countries group because group of lower middle income countries and upper middle income have low value of financial development index. The low index of financial development is illustrated by low value of the capital in the financial markets and the low domestic credit value thus inhibiting stability of financial system.

\subsection{Impact of Financial Inclusion of the Financial System Stability Based on Income Group Countries}

This is the result of regression using Tobit model to answer the impact of financial inclusion and other factors on financial stability based on income group countries:

Table 5.

Impact of Financial Inclusion and

other Factors on Financial Stability Based on Income Group Countries

\begin{tabular}{lccc}
\hline & LMIC & UMIC & HIC \\
\cline { 2 - 4 } & AFSI & AFSI & AFSI \\
\hline IFI & 0.3777 & $0.4568^{*}$ & $0.5142^{* *}$ \\
CGDP & $0.1965^{*}$ & $0.0239^{*}$ & 0.0673 \\
OPNS & 0.0004 & 0.0022 & $-0.0127^{*}$ \\
Cons & $0.4123^{* * *}$ & $0.4911^{* * *}$ & $0.5403^{* * *}$ \\
\hline
\end{tabular}

${ }^{* * *}$ : Significant level of $1 \%,{ }^{* *}$ : Significant level of $5 \%,{ }^{*}$ : Significant level of $10 \%$.

Table 5 shows that financial inclusion has a positive impact on the stability of the financial system in lower middle income countries group, but the effect is not significant. In upper middle and high income countries group, financial inclusion has a positive and significant impact with a significant level at $5 \%$ and $10 \%$, which means increasing in financial inclusion in terms of access, availability, and usability of financial services will improve the stability of financial system. This is due to increasing in financial inclusion illustrates the strengthening of real sector. In addition, increasing in financial inclusion will be followed by a strengthening of the base deposit that can be used to improve the process of intermediation (Khan, 2011).

Other variables that significantly affect financial stability are the ratio of private credit from bank deposits and other financial institutions of GDP and financial openness. The ratio of private credit from bank deposits and other financial institutions of GDP has a significant positive influence on stability of financial system over the group of lower and upper middle income countries with a significance level at $10 \%$, it means increasing in the ratio of private credit from bank deposits and other financial institutions to GDP will improve the stability of financial system. This is because increasing in private credit will lead to growth in the real sector and growth in financial sector that will strengthen the stability of financial system (Sahay et al., 2015).

Financial openness has a significant negative impact on stability of financial system in high-income countries at the level of $10 \%$. It means increasing in financial openness will reduce the stability of financial system due to high level of financial openness will increase the vulnerability to capital outflows from 
short-term capital when shocks occur. Capital outflow will be followed by volatile capital (depreciation of capital in the stock market) and the depreciation of the currency will eventually enhance instability in financial system (Estrada, Park, and Ramayandi, 2015).

\section{CONCLUSION}

\subsection{Conclusions}

Group of countries with higher income level has a better level of average access, availability, and usability of financial services so that it has higher value of financial inclusion index than lower income group. Group of countries with higher income level also has higher value of financial stability index than lower income group. The high average index of financial stability in group of countries with higher income due to many factors such as having high value of capital in the financial markets, having high concentrations of banking sector, having low level of inflation, and so on.

Financial inclusion has a positive impact but not significant to the stability of financial system in the group of lower income countries, but has a significant positive impact on the stability of financial system in upper middle income and high-income countries group. This is because increasing in financial inclusion illustrates the strengthening of the real sector in high-income countries group. In addition, the increase in financial inclusion will be followed by a strengthening of the base deposit that can be used to improve the process of banking intermediation (Khan, 2011).

\subsection{Recommendations}

1. For the government and the financial sector in lower middle income countries should encourage sub-index of financial development by encouraging capital flow in financial markets and enhancing domestic credit.

2. For the financial services authority and banking sector in upper middle and high income countries, to encourage financial stability can push financial inclusion by increasing bank capital to assets and reducing volatility of banking return on assets.

3. For further research, it's better to add low-income countries group if it has not problem of data availability.

4. One of lack of this research is only use data from 2004-2014, so it could not capture economic crisis in 1998-1999.

\section{REFERENCES}

Albulescu CT., \& Goyeau D. (2010). Assessing and Forecasting Romanian Financial System's Stability Using an Aggregate Index. Romanian Journal of Economic Literature, $1 / 2010$.

[CGAP] Consultative Group to Assist the Poor. (2013). Financial Access 2012 Getting to a More Comprehensive Picture. Washington DC (US) : CGAP.

Cull,R Kunt,D. (2007). Financial Performance and Outreach: A Global Analysis Leading Microfinance Institutions. The Economic Journal. 117(517), 107-133 
Dienillah,A.A. (2015). Dampak Inklusi Keuangan terhadap Stabilitas Sistem Keuangan di Asia. Bogor (ID) : Institut Pertanian Bogor.

Dupas,P Green,S Keats,A Robinson,J. (2012). Challenges in Banking the Rural Poor: Evidence from Kenya's Western Province. Cambridge (GB) : National Bureau of Economic Research.

Estrada G, Park D, Ramayandi A. (2015). Financial Development, financial openness, and Economic Growth. Tokyo: ADB economics Woking Paper Series 442.

Han, R., \& Melecky, M. (2013). Financial Inclusion for Financial Stability. Access to Bank Deposits and the Growth of Deposits in the Global Financial Crisis. Washington DC (US): World Bank.

Huang, R., \& Ratnovski, L. (2011). The Dark Side of Bank Wholesale Funding. Journal of Financial Intermediation, 20(2), 24-63.

Khan, H.R. (2011). Financial inclusion and financial stability: are they two sides of the same coin?. Chennai (IN): The Indian Bankers Association and Indian Overseas Bank.

Morgan, P., \& Pontines, V. (2014). Financial Stability and Financial Inclusion. Tokyo (JP) : Asian Development Bank Institute.

Sahay et al. (2015). Rethinking Financial Deepening:Stability and Growth in Emerging Markets. imf staff discussion note, 2016, from https://www.imf.org/ external/pubs/ft/sdn/ 2015/sdn1508.pdf

Sarma, M., \& Pais, J. (2008). Financial Inclusion and Development: A Cross Country Analysis. Berlin (GE): Berlin Working Papers on Money, Finance, Trade and Development.

World Bank. (2014). Jumlah rekening kredit per 1000 populasi dewasa. Retrieved February, 2016, from http://www.worldbank.org/. 